\title{
Recent Achievements and Challenge of Long Span Bridges in China
}

\author{
Hongmei Tan ${ }^{1,2 *}$ and Xiuping $\mathrm{Wu}^{1,2}$ \\ ${ }^{1}$ State Key Laboratory Breeding Base of Mountain Bridge and Tunnel Engineering, China \\ ${ }^{2}$ Mountain Bridge and Materials Engineering Research Center of Ministry of Education, China
}

ISSN: 2639-0574

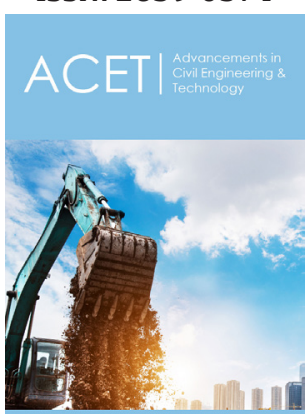

${ }^{* 1}$ Corresponding author: Hongmei Tan, State Key Laboratory Breeding Base of Mountain Bridge and Tunnel Engineering, Mountain Bridge and Materials Engineering Research Center of Ministry of Education, China

Submission: 䉑 May 21, 2019

Published: May 23, 2019

Volume 3 - Issue 2

How to cite this article: Hongmei $\mathrm{T}$, Xiuping W. Recent Achievements and Challenge of Long Span Bridges in China. Adv Civil Eng Tech. 3(2). ACET.000559.2019.

DOI: 10.31031/ACET.2019.03.000559

Copyright@ Hongmei Tan, This article is distributed under the terms of the Creative Commons Attribution 4.0 International License, which permits unrestricted use and redistribution provided that the original author and source are credited.

\section{Opinion}

Recently, bridges are becoming longer, wider and more sophisticated in China and over the world, in particular, with longer span length or so-called long span bridges. Nevertheless, achievements and challenge are coexisting in girder, arch, cable-stayed and suspension types.

\section{Long span girder bridges}

Girder bridges are most widely used bridge type with three sub-categories, simply supported system, continuous system and continuous rigid frame system. The current longest span of simply supported beam bridge is only $76 \mathrm{~m}$ while continuous beam bridge has the longest span of $165 \mathrm{~m}$. Continuous rigid frame bridge has the shortest history but the greatest bridging capacity in girder bridges. The span length of this type of girder bridge firstly exceeded 250m in Humen Bridge of $270 \mathrm{~m}$ China in 1997, and gradually increased to $330 \mathrm{~m}$ in the $2^{\text {nd }}$ Shibanpo Bridge in China in 2006.

For the $2^{\text {nd }}$ Shibanpo Bridge, the box girder bridge's long span was made economically and technologically feasible by using steel-concrete hybrid structures, within which a $103 \mathrm{~m}$ steel box girder in the middle of the $330 \mathrm{~m}$ main span, is connecting monolithically to the concrete box girder to reduce the weight of the structure. Therefore, the maximum hogging moment of the $330 \mathrm{~m}$ spanned hybrid girder is about the same as the $270 \mathrm{~m}$ spanned Humen Secondary Bridge with PC girder. However, the challenging problems encountered in prestressed concrete girder bridges are related to extreme bending moment, PC girder excessive deflection and orthotropic steel deck cracking.

Besides the traditional methods to reduce shrinkage and creep of concrete and anti-crack in PC webs, one of the most innovative ways is to adopt corrugated steel webs or steel truss webs in PC box girder, which can cut down $20 \sim 40 \%$ girder weight. In China, there are more than 300PC box girder bridges with corrugated steel webs since 2005 , while more than 100 bridges with steel truss webs.

\section{Arch bridges}

China has an ancient history of arch bridge construction for about 2,000 years, and the oldest existing bridge is Zhaozhou Bridge of $605 \mathrm{AD}$, which is the world's first whollystone open spandrel segmental arch bridge. In the past two decades, China has built several remarkable arch bridges with very long spans, including stone arch ribs (146m Danhe Bridge), concrete arch ribs (445m Beipanjiang Bridge), concrete-filled steel tube arch ribs (530m Bosideng Bridge), steel box arch ribs (550m Lupu Bridge) and steel truss arch ribs (552m Chaotianmen Bridge).

CFST (concrete-filled steel tube arch ribs) is an advanced steel-concrete composite structure with an external steel tube and internal filled plain concrete. The local stability of a steel tube is improved by the concrete filling it; besides, the toughness and strength of the concrete are improved by the external confinement of the steel tube. During the past 20 years, more than 400 CFST arch bridges have been constructed in China, with a maximum span of 
$530 \mathrm{~m}$. And now, a bridge call the third Pingnan Bridge is under construction, with a main span $560 \mathrm{~m}$. Arch bridges still have their own compressive challenges in buckling and/or instability of long span arch ribs and large horizontal resistance in foundation.

\section{Cable-stayed bridges}

In this century, the span length of cable-stayed Bridges over $1 \mathrm{~km}$ was realized in the $1088 \mathrm{~m}$ Sutong Bridge in 2008, the $1018 \mathrm{~m}$ Stonecutters Bridge in 2009 and the 1104m Russky Bridge in 2012, respectively. The construction of cable-stayed bridges began in China in 1975. Since then more than 300 cable stayed bridges have been completed, and over $85 \%$ of them have been built with prestressed or reinforced concrete decks. According to the statistics, among long-span concrete cable-stayed bridges, the longest span length is $500 \mathrm{~m}$ in Jinsha Yangtze River Bridge in Hubei Province completed in 2002.

Among long-span concrete cable-stayed bridges, more than half of them have been found in cracking of concrete decks with various cracks, which become the most challenge problem of structural durability. Through various investigations, most cracks can be identified in top plates, bottom plates, web plates and diaphragms.
The current cable-stayed bridge types with spatial cable planes and closed box girder may support to enlarged main span up to $1,400 \mathrm{~m}$ if the challenging problems of deck lateral bucking and stay cable vibration can be overcome.

\section{Suspension bridges}

Suspension Bridge is the old but longest type among these four types of bridge. Now, the longest box girder suspension bridge in the world is Xihoumen Bridge in China, a two-span suspension bridge with a main span of $1650 \mathrm{~m}$. For the purpose of wind resistance, for aerodynamic flutter stability, twin-box steel girder is adopted in this bridge. In which, the two boxes relate to a box section beam and an I-shaped beam at an interval of $18 \mathrm{~m}$ corresponding to the spacing of the bridge hangers.

In suspension bridge construction, the pilot rope pulling plays a very important role. There are many kinds of methods for pulling the pilot rope in China: using a tugboat, by helicopter, using rocket, and using unmanned aerial vehicle. The most challenging problem in suspension bridges is aerodynamic instability or so-called flutter, and some control measures must be adopted. 